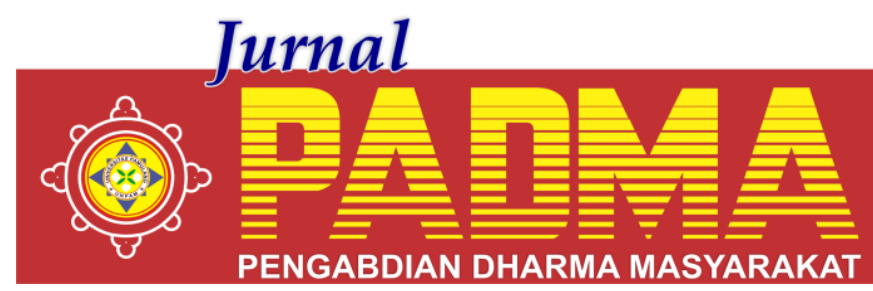

\title{
MENGEMBANGKAN KREATIFITAS REMAJA DAN MEMANFAATKAN SOSIAL MEDIA UNTUK MEDIA PROMOSI USAHA DIMASA PANDEMI
}

\author{
${ }^{1 *}$ Andri Kurniawan, ${ }^{2}$ Agung Prasetyo, ${ }^{3}$ Ali Robbi Hidayat, ${ }^{4}$ Andriko Prasetyo, \\ ${ }^{5}$ Anti Eri Susanti \\ Universitas Pamulang, Tangerang Selatan, Banten, Indonesia \\ *ak0123456andri@gmail.com
}

\begin{abstract}
Abstrak
Pelatihan usaha mikro ini untuk meningkatkan ekonomi keluarga dengan memanfaatkan teknologi yang ada, dalam hal ini lebih di khususkan smartphone karna lebih mudah di pelajari dan selalu di pakai dalam kegiatan sehari - hari. Kegiatan ini bertujuan untuk membantu para pelaku usaha mikro dan pemula dalam memanfaatkan teknologi melalui smartphone agar masyarakat setempat dapat meningkatkan ekonomi keluarga dengan tetap menajalankan usahanya meski pada saat pandemi Covid19
\end{abstract}

\section{Kata Kunci: Usaha Mikro, Online}

\section{Abstract}

This micro business training is to improve the family economy by utilizing existing technology, in this case it is more specifically a smartphone because it is easier to learn and always used in daily activities. This activity aims to help micro and beginner entrepreneurs in utilizing technology via smartphones so that local people can improve the family economy by continuing to run their business even during the Covid-19 pandemic.

Keywords: Micro Business, Online

\section{PENDAHULUAN}

Pemuda atau remaja merupakan salah satu generasi harapan bangsa yang keberadaanya sangat berperan dalam proses pembangunan bangsa, baik pembangunan dibidang ekonomi, politik, sosial dan budaya. Suatu bangsa yang besar sangat ditunjang oleh generasi mudanya, bagaimana sebuah negara bisa maju dan berkembang bila generasi mudanya tidak mempunyai kemampuan, keahlian baik dalam bidang pengetahuan, keterampilan yang dapat menunjang kehidupanya.

Demi mencapai tujuan nasional dilaksanakan berbagai upaya pembangunan dan pemberdayaan disegala bidang, baik sumber daya alam maupun sumber daya manusianya. Salah satu sumber daya yang sering menjadi permasalahan yaitu sumber daya manusia, yang berhubungan erat dengan kualitas manusia yang pada dasarnya sumber daya manusia itu adalah bagian dan generasi muda. Karena generasi muda inilah yang kelak akan meneruskan tongkat estafet kepemimpinan dimasa yang akan datang, sehingga kita membutuhkan generasi yang terampil, berakhlak, bermoral serta cinta tanah air dan dapat diandalkan di tengah masyarakat terutama bangsa dan negara.

Dalam proses pertumbuhan dan perkembangannya, terdapat generasi muda yang menyandang permasalahan sosial seperti kenakalan remaja, penyalahgunaan obat dan narkota, anak jalanan dan sebagainya baik yang disebabkan oleh faktor dari dalam dirinya (internal) maupun dari luar dirinya (eksternal). Jika hal itu tidak segera ditanggulangi akan dapat mengancam keberadaan dan kelangsungan hidup bangsa dan negara. Penurunan peranan dan kualitas diri terjadi di kalangan generasi muda, kreativitas, kemauan, dan kemampuan mengembangkan pemikiran untuk membangun bangsa yang ditujukan untuk kaderisasi yang baik dan berkompeten akan mengalami hambatan. Oleh karena itu perlu adanya upaya, 
program dan kegiatan yang secara terus menerus melibatkan peran serta semua pihak baik keluarga, lembaga pendidikan, organisasi pemuda, masyarakat dan terutama generasi muda itu sendiri.

Di RT.003/RW.008 Kelurahan Cirendeu banyak remaja dari kalangan usia sekolah maupun yang telah lulus saat pandemi tidak memiliki kegiatan yang dapat mengasah kemampuan, keterampilan dan kreatifitas mereka. Padahal kreatifitas sangat dibutuhkan, terutama dimasa pandemi ini. Kreatifitas dalam menciptakan usaha atau kreatifitas lain untuk menghilangkan stres dikala pandemi. Selain itu, penggunaan sosial media di kalangan remaja juga sangat tinggi. Namun penggunaan sosial media masih hanya sebatas untuk melihat info, padahal sosial media dapat dijadikan media untuk mempromosikan usaha atau bisnis kratif yang sedang atau akan dijalankan oleh masryarakat. Oleh karena itu, kami berinisiatif untuk melaksanakan Pengabdian Kepada Masyarakat (PKM) di Di RT.003/RW.008

Kelurahan Cirendeu, yang sebelumnya telah berkordinasi dan mendapatkan izin juga dari forum masyarakat Di RT.003/RW.008 Kelurahan Cirendeu (FORMASI 38).

\section{METODE}

Kegiatan dilakuakan secara offline dengan tetap memperhatikan PROKOTOL KESEHATAN. Remaja di lingkungan RT.003/RW.008 Kelurahan Cirendeu yang datang di wajibkan menggunakan masker, mencuci tangan dahulu dengan handsanitizer yang telah disediakan dan adanya pengukuran suhu tubuh serta jarak duduk antara para remaja 1 meter.

\section{HASIL DAN PEMBAHASAN}

Pembinaan generasi muda merupakan bagian dari pembangunan manusia Indonesia seutuhnya, sebagai kader penerus bangsa dan kader Pembangunan Nasional yang berdasarkan Pancasila dan UUD 1945. Pada buku Utami Munandar (2014:21) "kreativitas adalah kemampuan untuk membuat kombinasi-kombinasi baru yang mempunyai makna sosial". Defenisi
Haefele ini menunjukkan bahwa tidak keseluruhan produk itu harus baru tapi kombinasinya. pada buku Utami Munandar (2014:31) Dengan berkreasi mewujudkan (mengaktualisasikan) dirinya, dan perwujudan/aktualisasi diri merupakan kebutuhan pokok pada tingkat tertinggi dalam hidup manusia.

Kendala Dalam Pengembangan Kreativitas:

1. Evaluasi. Menekankan salah satu syarat untuk memupuk kreativitas konstruktif ialah pendidikan yang tidak memberikan evaluasi, atau menunda pemberian evaluasi sewaktu anak sedang asyik berkreasi. Menduga akan dievaluasi pun akan mengurangi kreativitas anak. Pujian dapat membuat anak kurang kreatif, karena pujian membuat mereka memusatkan perhatian pada harapan akan dinilai. Perasaan diamati saat bekerja dapat mengurangi kreativitas seseorang.

2. Hadiah. Pemberian hadiah kepada anak dapat merusak motivasi intrinsik dan mematikan kreativitas.

3. Persaingan (kompetisi). Kompetisi merupakan hal yang lebih kompleks dari evaluasi dan hadiah, karena kompetisi mencakup kedua hal tersebut. Biasanya

4. persaingan terjadi apabila siswa merasa bahwa pekerjaannya akan dinilai terhadap pekerjaan siswa lain dan bahwa yang terbaik akan menerima hadiah.

5. Lingkungan yang Membatasi. Belajar dan kreativitas tidak dapat ditingkatkan dengan paksaan. Seorang anak mempunyai pengalaman sekolah yang sangat menekankan pada disiplin dan hafalan. Ia selalu diberitahu apa yang harus dipelajari, bagaimana mempelajarinya, dan pada ujian harus dapat mengulanginya dengan tepat, pengalaman yang baginya sangat menyakitkan dan menghilangkan minatnya terhadap ilmu, meskipun hanya untuk sementara.

Manfaat Pemasaran Melalui Sosial Media:

1. Membangun dan Menarik Minat Masyarakat. Menggunakan media sosial sebagai media pemasaran merupakan 
pilihan yang tepat, karena kemampuan sosial media yang dapat membangun dan menarik minat masyarakat. Bagi pelaku bisnis, Anda akan diuntungkan dengan hal ini karena dengan sosial media Anda bisa dengan mudah menarik minat masyarakat terhadap produk atau jasa yang Anda jual.

2. Membantu Menemukan Konsumen dan Memperluas Target Pemasaran. Media sosial seperti facebook dan instagram membantu para pembisnis kecil untuk menemukan konsumen yang potensial. Jika Anda ingin meperluas target pemasaran menggunakan media sosial sebagai medianya sangatlah tepat.

3. Memudahkan Mendapat Feedback Secara Langsung. Menggunakan sosial media sebagai media pemasaran memberikan Anda akses untuk menerima feedback positif maupun negatif dari konsumen dimana informasi tersebut sangatlah berharga sebagai bahan evaluasi kedepannya.

4. Mengembangkan Target Pasar dan Dapat Menyaingi Kompetitor. Dengan media sosial Anda bisa mendapat informasi yang penting tentang kompetitor dengan begitu Anda bisa meningkatkan strategi pemasaran.

5. Meningkatkan Jumlah Penjualan Produk. Manfaat dari pemasaran melalui sosial media yang paling penting ialah meningkatnya jumlah penjualan produk Anda.

\section{PENUTUP}

Kemampuan, keterampilan dan kreatifitas remaja perlu dikembangkan sebagai langkah pertama upaya pembangunan sumber daya manusia yang pada akhirnya dapat membangun bangsa, baik pembangunan di bidang ekonomi, politik, sosial dan budaya. Kondisi remaja yang dekat dengan teknologi menjadi potensi tersendiri bagi mereka, kedekatan para remaja dengan teknologi sebagai modal dasar mengarahkan mereka supaya memaksimalkan penggunaan teknologi, untuk hal-hal yang bermanfaat dan bernilai. Penggunan teknologi yang maksimal ini, dapat mendorong kreatifitas para remaja. Sosial media sebagai salah satu bentuk penggunaan teknologi yang dapat mendorong kreatifitas remaja, yakni dengan menjadikan sosial media tersebut sebagai media promosi usaha atau bisnis kratif yang sedang atau akan dijalankan oleh masryarakat.

\section{DAFTAR PUSTAKA}

Ajimat, A., Sunarsi, D., \& Sidiq, F. (2020). Berwirausaha Memanfaatkan Media Sosial Pada Daerah Sepatan. ADI Pengabdian Kepada Masyarakat, 1(1), 69-76.

Erlangga, H. (2020). The Challenges of Organizational Communication in the Digital Era. Solid State Technology, 63(4), 1240-1246.

Munandar, Utami. (2014). Pengembangan Kreativitas Anak Berbakat. Jakarta: Rineka Cipta.

Supriyadi, D., et al (2020) Innovation And Authentic Leadership of Islamic University Lectures In Faculty Pharmacy Faculty: What Is The Role Of Psychological Capital?. Systematic Reviews in Pharmacy, 11 (8), 383-393. doi:10.31838/srp.2020.8.56.

Https://ibrand.id/manfaat-pemasaranmelalui-media-sosial/

Https://www.bappenas.go.id/index.php/do wnloadfile/view/8552/1717/ 